Research Article

Open Access

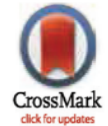

${ }^{\mathbf{1}}$ Department of Home Economics, College of Education Jigawa State, Nigeria

${ }^{2}$ Department of Food Science and Technology, Faculty of Agriculture, Bayero University, Kano

${ }^{3}$ College of Biosystems Engineering and Food Science, National-Local Joint Engineering Laboratory of Intelligent Food Technology and Equipment, Zhejiang Key Laboratory for Agro-Food Processing, Zhejiang R \& D Center for Food Technology and Equipment, Zhejiang University, Hangzhou 310058, China.

${ }^{4}$ Department of Microbiology, Kano University of Science and Technology Wudil, Kano State Nigeria

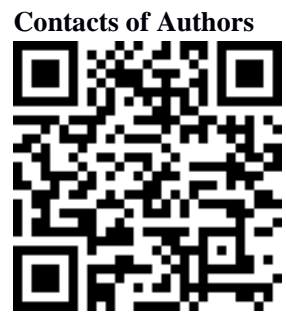

To whom correspondence should be addressed: Sanusi Shamsudeen Nassarawa

Citation: Zaharaddeen Salisu, Sanusi Shamsudeen Nassarawa and Sadisu Farouq (2020). Microbial quality assessment of roasted and fried meat sold in Gumel town. Highlights in BioScience Volume 3. Article ID 20222. dio:10.36462/ H.BioSci.20222

Received: June 17, 2020

Accepted: September 7, 2020

Published: September 20, 2020

Copyright: (C) 2020 Salisu et al. This is an open access article distributed under the terms of the Creative Commons Attribution License, which permits unrestricted use, distribution, and reproduction in any medium, provided the original author and source are credited.

Data Availability Statement: All relevant data are within the paper and supplementary materials

Funding: The authors have no support or funding to report.

Competing interests: The authors declare that they have no competing interests.

\section{Microbial quality assessment of roasted and fried meat sold in Gumel town}

\section{Zaharaddeen Salisu ${ }^{1}$, Sanusi Shamsudeen Nassarawa ${ }^{2,3} *$ and Sadisu Farouq $^{4}$}

\section{Abstract}

Roasted and fried meats are the two commonest and preferred meat varieties consumed in northern Nigeria. The consumption of these meat varieties is, nevertheless, without ascertaining its fitness in terms of contamination by pathogens. In line with this occurrence and preference, it is a good approach to assess the quality of roasted and fried meat in one of the prehistoric towns of northern Nigeria, which is Gumel. A total of 10 samples of both fried and roasted meat were randomly collected, prepared and microbiological analyses for mesophilic bacteria, fungi and coliform group conducted in the laboratory. The mean bacterial load was observed between $3.0 \times 10^{4}$ and $6.5 \times 10^{4} \mathrm{CFU} / \mathrm{g}$ for roasted beef meat and $4.7 \times 10^{4}$ and $5.3 \times 10^{4} \mathrm{CFU} / \mathrm{g}$ for fried beef meat. It was $4.5 \times 10^{4}$ and $6.0 \times 10^{4} \mathrm{CFU} / \mathrm{g}$ in roasted chicken meat and $4.0 \times 10^{4}$ and $4.7 \times 10^{4}$ $\mathrm{CFU} / \mathrm{g}$ in fried chicken meat. For the fungal load, it was observed to be between the range of $1.0 \times 10^{4}$ and $3.0 \times 10^{3} \mathrm{CFU} / \mathrm{g}$ for roasted beef meat and $1.0 \times 10^{4}$ and $7.0 \times 10^{3} \mathrm{CFU} / g$ for fried beef meat. For the chicken meat, it ranges from $1.0 \times 10^{4}$ to $4.0 \times 10^{3} \mathrm{CFU} / \mathrm{g}$ for the roasted type and $1.0 \times 10^{4}$ and $7.0 \times 10^{3} \mathrm{CFU} / \mathrm{g}$ for the fried meat. Investigation of the coliform group showed no growth in both samples. On biochemical tests, bacterial species confirmed to be present were Staphylococcus aureus, Bacillus spp, and Streptococcus spp. while Penicillium spp, Mucor hiemalis, Aspergillus species and Rhizopus spp. are the fungal species observed in the meats. This research was, therefore, conducted to assess the quality of roasted and fried meat sold in Gumel town to relate it to some common diseases affecting the community.

Keywords: Roasted meat, fried meats, microbial quality assessment.

\section{Introduction}

Meat is mainly composed of water and protein and is usually eaten together with other foods. It has been reported that meat is rich in protein (15-20\%), minerals, vitamins, and all the essential amino acids. Meat is animal flesh that is eaten as food [1]. Humans are omnivorous and have hunted and killed animals for meat since prehistoric times [2,3]. The advent of civilization allowed for the domestication of animals such as chickens, sheep, fish, seafood, pigs, and cattle and eventually their use in meat production on an industrial scale. It is edible raw but is normally eaten after it has been cooked and seasoned or processed in a variety of ways. Meat consumption varies worldwide, depending on cultural and religious differences, as well as the socio-economic status of the people. Nigerians depend mainly on domestic animals and aquatic organisms and to some extent on game animals and birds. This is true of the urban as well as rural communities [4]. Unprocessed meat will spoil within hours or days. 
Spoilage is caused by the practically unavoidable infection and subsequent decomposition of meat by bacteria and fungi, which are born by the animal itself, people handling the meat and their implements [5]. Because of this, meat nowadays serves as a source of various foodborne diseases due to improper processing, handling and storage. This usually results in the reduction of valuable proteins and leads to various foodborne infections. However, considering the random addiction of eating meat anyhow in mostly states of Northern Nigeria without ascertaining its fitness in terms of contamination by either bacteria or fungi, which is mostly attributed to the lack of good knowledge on the possible spoilage, it is pertinent to set up a mechanism that will be geared towards investigating the possible contamination sources and assess the quality of roasted and fried meat sold in Gumel town, one of the prehistoric towns of northern Nigeria.

\section{Materials and Methods}

This research was conducted at Gumel town, one of the Local Governments of Jigawa State, Nigeria. It is located at latitude $12.63^{\circ} \mathrm{N}$ and longitude $9.30^{\circ} \mathrm{E}$ and 36 meters elevation above the sea level with an estimated population of about 42,742. A total of 10 samples comprising three fried and roasted beef meat each, and two fried and roasted chicken meat were randomly collected from the study area. The samples were placed into cleaned polythene bags and transported immediately to the laboratory for preparation and subsequent analysis. All the media used in this study were prepared and handled according to the manufacturer's instructions. For the enumeration of aerobic mesophilic bacteria and fungi, the social dilution method, as described by the American Public Health Association [6], was employed.

Plates containing between 30 and 300 colonies were selected and counted for bacteria, and the number obtained was multiplied by the dilution factor. This gave the number of bacterial colony-forming units per gram of meat samples (CFU/g of the meat sample). For fungi, the plate that contained less than 50 colonies were selected and counted after 3-5-day incubation period. The count was reported as fungi/mold colony forming a gram of meat sample (CFU/g). Sets of control for each sample containing agar and diluents were also incubated to ascertain the sterility of the media. The following formula was used to calculate the number of bacteria/fungi colony forming units per gram of the meat.

$\mathrm{N}=n / v d$; Where: $\mathrm{N}=$ the number of bacterial/fungal colonies per gram of sample; $\mathrm{n}=$ number of colonies counted; $v=$ volume of sample used; $d=$ dilution factor.

For the enumeration of mesophilic coliform bacteria, the three tube method described by [6] was employed. The color, size, shape and microscopy (for Gram staining), surface elevation and margin of different colonies developed on the plates were observed. A representative colony of the various morphological types was picked and transferred to a freshly prepared, sterilized and solidified nutrient agar incubated at $35^{\circ} \mathrm{C}$ for 24 hours to obtain a pure culture of the organisms [6]. The isolated organisms were then subjected to grams staining techniques, and microscopy then followed.

The fungal isolates were identified as described in the illustrated genera of imperfect fungi [7] and microbiological methods [8]. Catalase tests coagulate test, methyl red-Voges Proskauer, citrate test, urease test, motility test and indole test were all carried out according to the method described by Cheesbrough [9].

\section{Results and Discussion}

The results of bacterial colony counts (colony-forming units per gram, CFU/g) as presented in Table 1 for the beef meat were observed to be within the range of $3.0 \times 10^{4}$ to $6.5 \times 10^{4}$ and $4.7 \times 10^{4}$ to $5.3 \times 10^{4} \mathrm{CFU} / \mathrm{g}$ for roasted and fried beef meat, respectively.

Table 1. Total bacterial count of roasted and fried meats in beef and chickens.

\begin{tabular}{l|lll}
\hline S/N & Sample & $\begin{array}{c}\text { Bacterial colony count per } \\
\text { gram of sample (CFU/g) }\end{array}$ & Log No. \\
\hline $\mathbf{1}$ & BR-1 & $3.5 \times 10^{4}$ & 4.5 \\
$\mathbf{2}$ & BR-2 & $6.5 \times 10^{4}$ & 4.8 \\
$\mathbf{3}$ & BR-3 & $3.0 \times 10^{4}$ & 4.5 \\
$\mathbf{4}$ & BF-1 & $4.7 \times 10^{4}$ & 4.7 \\
$\mathbf{5}$ & BF-2 & $3.8 \times 10^{4}$ & 4.6 \\
$\mathbf{6}$ & BF-3 & $5.3 \times 10^{4}$ & 4.7 \\
$\mathbf{7}$ & CR-1 & $4.5 \times 10^{4}$ & 4.7 \\
$\mathbf{8}$ & CR-2 & $6.0 \times 10^{4}$ & 4.8 \\
$\mathbf{9}$ & CF-1 & $4.7 \times 10^{4}$ & 4.7 \\
$\mathbf{1 0}$ & CF-2 & $4.0 \times 10^{4}$ & 4.6 \\
\hline
\end{tabular}

KEY: BR=Roasted beef meat, $\mathrm{BF}=$ Fried beef meat, $\mathrm{CR}=$ Roasted Chicken meat $\mathrm{CF}=$ Fried chicken meat

In comparison, it was observed to be within the range of $4.5 \times 10^{4}$ to $6.0 \times 10^{4}$ and $4.0 \times 10^{4}$ to $4.7 \times 10^{4} \mathrm{CFU} / \mathrm{g}$ for roasted and fried chicken meat, respectively. These values obtained for the mean bacterial and fungal loads were within the acceptable range of $1 \times 10^{3}$ to $1 \times 10^{7}$ $\mathrm{CFU} / \mathrm{g}$ as provided by Ledward [10] and $1.0 \times 10^{3}$ for the acceptable limits for the ready to eat foods and is an indication that the meat was processed thoroughly because Heetun et al. [11] reported that meat and meat products are highly perishable commodities and if not properly stored, processed, packed and distributed microbial growth will be highly accelerated. The level of microorganisms present in meat products as reported by Jay et al. [12] can be reduced 
only when they are further processed. Another report Davies and Board [13] has revealed that if spoilage microorganisms such as Brochothrix thermosphacta and Pseudomonas spp. are present and grow to a high number, the meat will spoil and will be unfit for human consumption. The total fungal count (Table 2) was observed to range between $1.0 \times 10^{4}$ to $3.010^{3}$ and $1.0 \mathrm{x}$ $10^{4}$ to $7.0 \times 10^{3} \mathrm{CFU} / \mathrm{g}$ for roasted and fried beef meat, respectively. It was, however, observed that in chicken meat, it ranged between $1.0 \times 10^{4}$ to $4.0 \times 10^{3}$ and $1.0 \times 10^{4}$ to $7.0 \times 10^{3} \mathrm{CFU} / \mathrm{g}$ for roasted and fried meat variety.

Table 2. Fungal count of roasted and fried meat (beef and chickens).

\begin{tabular}{l|lll}
\hline S/N & Sample & $\begin{array}{l}\text { Fungal colony count per } \\
\text { gram of sample (CFU/g) }\end{array}$ & Log No. \\
\hline $\mathbf{1}$ & BR-1 & $1.0 \times 10^{4}$ & 4.0 \\
$\mathbf{2}$ & BR-2 & $3.0 \times 10^{3}$ & 3.5 \\
$\mathbf{3}$ & BR-3 & $1.0 \times 10^{4}$ & 4.0 \\
$\mathbf{4}$ & BF-1 & $1.0 \times 10^{4}$ & 3.8 \\
$\mathbf{5}$ & BF-2 & $4.0 \times 10^{3}$ & 3.6 \\
$\mathbf{6}$ & BF-3 & $7.0 \times 10^{3}$ & 3.8 \\
$\mathbf{7}$ & CR-1 & $4.0 \times 10^{3}$ & 3.6 \\
$\mathbf{8}$ & CR-2 & $1.0 \times 10^{4}$ & 4.0 \\
$\mathbf{9}$ & CF-1 & $1.0 \times 10^{4}$ & 4.0 \\
$\mathbf{1 0}$ & CF-2 & $7.0 \times 10^{3}$ & 3.8 \\
\hline
\end{tabular}

KEY: BR=Roasted beef meat; $\mathrm{BF}=$ Fried beef meat; $\mathrm{CR}=$ Roasted Chicken meat; $\mathrm{CF}=$ Fried chicken meat.

In the same vain, Ismail et al. [14] studied the microbial quality of some meat products obtained from local markets in Egypt, and reported many types of fungi belonging to several genera such as Aspergillus, Candida, Cladosporium, Eupenicillium, Eurotium, Geotrichum,
Mucor, Penicillium, Rhototorula besides aflatoxin B1. These researchers also isolated Clostridium perfringens and Staphylococcus aureus. In this scenery, Yousuf et al. [15] have elaborated that the presence of coliforms such as Escherichia coli in food is suggestive of faecal contamination from animals. The results of the most probable number index per gram of coliform of the roasted and fried meats of beef and chickens (Table 3) showed no growth in all samples.

Table 3. Results of the most probable number index per gram of coliform of the roasted and fried meat (beef and chickens)

\begin{tabular}{l|lll}
\hline S/N & Sample & MPN per gram & Log Number \\
\hline $\mathbf{1}$ & BR-1 & No growth & - \\
$\mathbf{2}$ & BR-2 & No growth & - \\
$\mathbf{3}$ & BR-3 & No growth & - \\
$\mathbf{4}$ & Bf-1 & No growth & - \\
$\mathbf{5}$ & Bf-2 & No growth & - \\
$\mathbf{6}$ & BF-3 & No growth & - \\
$\mathbf{7}$ & CR-1 & No growth & - \\
$\mathbf{8}$ & CR-2 & No growth & - \\
$\mathbf{9}$ & CR-1 & No growth & - \\
$\mathbf{1 0}$ & CR-2 & No growth & - \\
\hline
\end{tabular}

KEY: $\mathrm{BR}=$ Roasted beef meat; $\mathrm{BF}=$ Fried beef meat; $\mathrm{CR}=$ roasted Chicken meat; $\mathrm{CF}=$ Fried chicken meat.

The results of morphological characterization of the bacterial and fungal isolates (Tables 4 and 5) showed some colonies of bacteria appearing yellow and some whitish. Most of the fungal colonies, when stained with lactophenol stain appeared blackish, brown and greenish with characteristic section.

Table 4. Morphology of the bacterial isolates in meat samples (beef and Chicken).

\begin{tabular}{l|lllllllllll}
\hline $\mathbf{S} / \mathbf{N}$ & Isolate & Br-1 & Br-2 & Br-3 & Bf-1 & Bf-2 & Bf-3 & Cr-1 & Cr-2 & Cf-1 & Cf-2 \\
\hline $\mathbf{1}$ & $\mathrm{A}_{1}$ & + & + & + & + & + & + & + & + & + \\
$\mathbf{2}$ & $\mathrm{B}_{1}$ & + & + & - & - & + & - & + & + & - & - \\
$\mathbf{3}$ & $\mathrm{C}_{1}$ & + & - & + & + & + & + & - & - & + & + \\
\hline
\end{tabular}

Key: $+=$ growth observed; - = growth was not observed.

Table 5. Morphology of the bacterial isolates in meat samples (beef and Chicken).

\begin{tabular}{l|lllllllllll}
\hline $\mathbf{S} / \mathbf{N}$ & Isolate & Br-1 & Br-2 & Br-3 & Bf-1 & Bf-2 & Bf-3 & Cr-1 & Cr-2 & Cf-1 & Cf-2 \\
\hline $\mathbf{1}$ & $\mathrm{A}_{2}$ & - & + & + & - & + & + & + & + & + \\
$\mathbf{2}$ & $\mathrm{B}_{2}$ & & - & - & - & + & + & + & + & + & + \\
$\mathbf{3}$ & $\mathrm{C}_{2}$ & + & + & + & + & + & + & - & - & - & + \\
$\mathbf{4}$ & $\mathrm{D}_{2}$ & + & - & - & + & - & + & - & - & - & + \\
\hline
\end{tabular}

Key: + = growth observed; $-=$ growth was not observed. 
Table 6. Biochemical tests of bacterial isolates from roasted and fried meats (beef and chickens).

\begin{tabular}{|c|c|c|c|c|c|c|c|c|c|c|}
\hline Isolate & Microscopy & $\begin{array}{l}\text { Gram } \\
\text { reaction }\end{array}$ & Coagulase & $\begin{array}{l}\text { Carbohydrate } \\
\text { fermentation }\end{array}$ & Indole & $\begin{array}{l}\text { Methyl } \\
\text { red }\end{array}$ & $\begin{array}{l}\text { Voges } \\
\text { proskaver }\end{array}$ & Citrate & Motility & $\begin{array}{l}\text { Expected } \\
\text { organism } \\
\end{array}$ \\
\hline A1 & $\begin{array}{l}\text { Cocci in } \\
\text { Closter }\end{array}$ & - & + & - & - & + & - & - & + & $\begin{array}{l}\text { Staphylococcus } \\
\text { aureus }\end{array}$ \\
\hline B1 & Short rod & + & + & + & - & + & - & - & - & Baccilus spp \\
\hline C1 & $\begin{array}{l}\text { Cocci in } \\
\text { chain }\end{array}$ & + & - & - & - & + & - & + & - & $\begin{array}{l}\text { Streptococcus } \\
\text { spp }\end{array}$ \\
\hline
\end{tabular}

Key: + = presence; - = Absence

The fungal species isolated as presented in Tables (6 and 7) were Penicillium spp, Mucor hiemalis, Aspergillus species and Rhizopus spp. On biochemical tests, the bacterial species confirmed to be present are Staphylococcus aureus, Baccilus spp, and Streptococcus spp Table 6.

Table 7. Fungal isolation and identification of roasted and fried meats (beef and chickens).

\begin{tabular}{l|ll}
\hline S/N & Isolate & Expected organism \\
\hline 1 & $\mathrm{~A}_{2}$ & Penicillium $\mathrm{spp}$ \\
2 & $\mathrm{~B}_{2}$ & Mucor hiemalis \\
3 & $\mathrm{C}_{2}$ & Aspergillus spp \\
4 & $\mathrm{D}_{2}$ & Rhizopus nigricans \\
\hline
\end{tabular}

\section{Conclusion}

It can be concluded that the total bacterial and fungal counts of both roasted and fried meats prepared and sold by commercial meat sellers in Gumel town in Nigeria was found to fall within the standard range endorsed by WHO and other international organizations. Hence, contained fewer contaminants, and this can be attributed to the hygienic conditions of utensils, water and the ingredients used in processing the meat.

\section{References}

1. Cross AJ, Leitzmann MF, Gail MH, Hollenbeck AR, Schatzkin A, Sinha R. A prospective study of red and processed meat intake in relation to cancer risk. PLoS Med. 2007 Dec 11;4(12):e325.

2. Wildman R, Medeiros D. Advanced human nutrition. Boca Raton: CRC Press;2000

3. Miller, R.K., (2002). Factors affecting the quality of raw meat, In Meat processing improving quality. Joseph, K., K. John and D. Ledward (Eds.), CRC Press, FL, USA, 26-63. ISBN: 978-1-59124-484-4.

4. Ikeme AI.Meat Science and Technology: A Comprehensive Approach. Published By African Fep Publisher Limited Onitsha, Nigeria; 1990.

5. Shakuntala NMM, Shadak S . Food Facts and Principles 2nd Edition Published K.K Gupta for Bassir New Age Inter (P) Ltd; 2001.

6. APHA. American Public Health Association; 1992.
7. Burnett HL, Hunter BB .Illustrated Genera of Imperfect Fungi 3rd Edition. Minneapolis: Burgess Publishing Company; 1972.

8. Collins CH, Lyne PM. London:Microbiological Method 4th Edition Butterworth; 1976.

9. Cheesbrough M. District laboratory practice in Tropical countries, part 2. Cambridge University Press, Cambridge. 2000;p.47 - 54.

10. Ledward DA. Lawries Meat Science 17th Ed. Cambridge: Wood head Publishing Limited; 2006.

11. Heetun I, Goburdhun D, Neetoo H. Comparative microbiological evaluation of raw chicken from markets and chilled outlets of Mauritius. Journal of World's Poultry Research; 2015:5: 10-18.

12. .Jay JM, Loessner MJ, Golden DA. Modern Food Microbiology. 7th ed. New York(USA): Springer Science and Business Media;2005.

13. Davies A, Board R. The microbiology of meat and poultry. Aspen Publishers, Inc., Gaithersburg, MD; 1998.

14. Ismail SA, Shehta AA, El-diasty EM. Microbiological quality of some meat products in local markets with special reference to mycotoxins. Global Veterinaria; 2013:10: 577-584.

15. Yousuf AHM, Ahmed MK, Yeasmin S, Ahsan N, Rahman MM, Islam MM. Prevalence of microbial load in Shrimp, Penaeusmonodon and Prawn, Macrobrachium rosenbergii from Bangladesh. World Journal of Agricultural Sciences; 2008:4: 852- 855. 